\title{
The 'Sokal affair' takes transatlantic turn
}

[LONDON] A dispute that has been simmering since last summer in the United States over the validity of 'postmodernist' ideas about the nature of scientific knowledge has finally reached the point where many such ideas originated - the banks of the river Seine in Paris.

Over the past month, the newspaper Le Monde has been running a series of articles triggered by an account of the widely publicized hoax perpetrated last year by Alan Sokal, a theoretical physicist at New York University, on the journal Social Text.

The hoax took the form of an article submitted to and accepted by the journal. It purported to demonstrate the social and political origins of ideas in quantum mechanics - but in fact was fabricated out of miscellaneous (but accurate) quotations from prominent postmodern writers and dubious statements of scientific 'fact'.

Sokal's article has added fuel to a conflict that has been growing in recent years between scientists who argue that science is based on empirical fact, and sociologists of science who argue that much of scientific knowledge is 'constructed' out of debates between researchers (see, for example, Nature 375, 439; 1995).

In the United States, the hoax article and its implications - namely that sociologists of science have little regard for empirical truth and are more interested in intellectual fashions - has set off a wide debate on university campuses. "The reaction has been a factor of ten bigger than I expected," says Sokal. "And it is not letting up."

Until now, the response in Europe has been relatively muted, even though many of the writers quoted tend to be European, usually either British or French. The main reaction has been a defence of European academics whose work and US colleagues have come under attack.

\section{Petitions, postmodernism and politics}

Last October, for example, many of those attending a joint meeting of the US-based Society for Social Studies in Science and the European Association for Studies of Science and Technology, held in Bielefeld in Germany, signed a petition protesting that some of the recent US criticism of work by sociologists of science could, in Europe, be regarded as potentially defamatory.

But the recent series of articles in Le Monde, widely regarded as the main public forum for both intellectual and political debate in France, as well as coverage in French publications Libération and Le Nouvel Observateur, indicate that the issue is now hotting up in Europe too.

Further evidence comes from the fact that an article by Paul Boghassian, a philosopher also at New York University, attacking postmodernist views of science, which appeared in the Times Literary Supplement in December, has already been published in Die Zeit, one of Germany's leading newspapers.

One of Sokal's strongest supporters is Jean Bricmont, a theoretical physicist at the University of Louvain in Belgium. He is writing a book with Sokal on what both argue is the frequent misuse of scientific concepts by prominent - and mainly French intellectual figures ranging from the psychoanalyst Lacan to Bruno Latour, an influential sociologist of science.

\section{When is a fact is not fact?}

Bricmont wrote in his contribution to the debate in Le Monde that such allusions tended to be "at best totally arbitrary and at worse erroneous". He says he is keen to see a reinstatement of ideas about science based on empiricism and the analytical philosophy of individuals such as the mathematician Bertrand Russell, rather than those of German idealists such as the philosopher Martin Heidegger.

He says he is concerned at a growing tendency to see ideas in socially relative terms, criticizing, for example, official guidelines on epistemology used by highschool teachers in Belgium for stating that a fact is not an empirical truth, but "something that every one agrees upon".

Like Sokal, Bricmont says that he has been surprised by the level of interest he has stirred up. "I seem to have put my finger on something bigger than I realized," he says.

But some of those under attack, having initially held back from the fray on the grounds that the debate was primarily based on issues internal to the United States, are now fighting back, arguing that it is

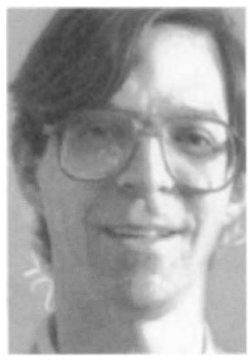
their critics who have an idealistic - and increasingly outdated - vision of science and its role in contemporary culture.

Last week, for example, Latour, who teaches the sociology of innovation at the Ecole Sokal: hoax article set Supérieure des Mines off enormous debate. in Paris, one of France's so-called 'grandes écoles', complained in Le Monde that he and fellow sociologists were being treated as "drug peddlers" who were corrupting the minds of American youth.

In fact, says Latour, one of his main concerns has been to demonstrate how modern society - as reflected in the public response to concerns about bovine spongiform encephalopathy ('mad cow disease') is transforming itself from a culture "based

on Science, with a capital S", to one based on research more broadly, including the social sciences.

He writes: "In place of an autonomous and detached science, whose absolute knowledge allows us to extinguish the fires of political passions and subjectivity, we are entering a new era in which scientific controversybecomes part of political controversy."

\section{IMAGE UNAVAILABLE
FOR COPYRIGHT REASONS} The latest salvo in the French debate comesfrom Sokal himself. In a response due to be published this week, Sokal repeats his claim that every scientist is aware that, although scientific knowledge is Russell: pursued an always partial and subanalytical approach. ject to revision, "that does not prevent if from being objective".

Sokal eschews charges of chauvinism, saying that his target is not - as some have suggested-French intellectuals as such, but "certain intellectuals who happen to live in France". He also dismisses the criticism that his concern about the growing influence of growth of 'constructivist' ideas about science reflects worries about a decline in both funding for physics and the social status with the end of the Cold War.

\section{Differences in culture and education}

But Latour, too, who makes both claims, has his supporters - and not just in France. Simon Schaffer, a lecturer in the history and philosophy of science at the University of Cambridge, points to the irony that Latour and others are trying to develop the public understanding of science that, in other contexts, Sokal and others argue is essential if they are to retain respect.

Schaffer also points to the different cultural environments, partly a product of different educational traditions, in which French and American scientists operate. "In France, everyone believes that the sciences are self-validating, and that the social sciences refer to a world that exists outside themselves," he says.

In contrast, he argues, the empiricism that tends to dominate the Anglo-American approach to science means that "no-one in the scientific community sees themselves as an epistemologist or a constructivist".

With Europe facing important issues concerning the relationship between science and politics - ranging from the likely science policy of the British Labour party if it wins the imminent general election, to the squeeze by Germany on international spending on particle physics - the public debate set alight by Sokal appears unlikely to die down rapidly.
DavidDickson 